\title{
Peran Badan Nasional Pengelola Perbatasan Di Dalam Melakukan Pengawasan Terhadap Perbatasan Indonesia \\ (The Role Of The National Border Management Authority Republic Of Indonesia In Supervising Indonesia's Borders)
}

\author{
Dwinta Nurul Puteri \\ Magister Hukum Universitas Indonesia \\ Jl. Salemba Raya No.4, RW.5, Kenari, Kec. Senen, Kota Jakarta Pusat, Daerah Khusus Ibukota \\ Jakarta 10430
}

\begin{abstract}
Pengelolaan batas wilayah negara pada dasarnya dilakukan untuk mencapai keberadaan arah strategis mewujudkan kawasan perbatasan sebagai wilayah yang aman, baik secara kedaulatan negara, ketertiban, serta keamanan kawasan. Konstitusi Indonesia, khususnya pada Pasal 25A Undang-Undang Dasar Tahun 1945 (UUD 1945) menyatakan bahwa "Negara Kesatuan Republik Indonesia adalah sebuah negara kepulauan yang berciri Nusantara dengan wilayah yang batas-batas dan hak-haknya ditetapkan dengan undang-undang”. Melihat UndangUndang Nomor 43 Tahun 2008 Tentang Wilayah Negara dan Peraturan Presiden Nomor 44 Tahun 2017 Tentang Perubahan Atas Peraturan Presiden Nomor 12 Tahun 2010 Tentang Badan Nasional Pengelola Perbatasan yang mengamanatkan tugas BNPP yaitu menetapkan kebijakan program pembangunan perbatasan, menetapkan rencana kebutuhan anggaran, mengkoordinasikan pelaksanaan; dan melaksanakan evaluasi dan pengawasan. Sedangkan pelaksana teknis pembangunan dilakukan oleh instansi teknis sesuai tugas pokok dan fungsinya.
\end{abstract}

Keywords: Border, National Border Management Authority Republic Of Indonesia, Indonesia.

\begin{abstract}
Abstrak. Pengelolaan batas wilayah negara pada dasarnya dilakukan untuk mencapai keberadaan arah strategis mewujudkan kawasan perbatasan sebagai wilayah yang aman, baik secara kedaulatan negara, ketertiban, serta keamanan kawasan. Konstitusi Indonesia, khususnya pada Pasal 25A Undang-Undang Dasar Tahun 1945 (UUD 1945) menyatakan bahwa "Negara Kesatuan Republik Indonesia adalah sebuah negara kepulauan yang berciri Nusantara dengan wilayah yang batas-batas dan hak-haknya ditetapkan dengan undang-undang”. Melihat Undang-Undang Nomor 43 Tahun 2008 Tentang Wilayah Negara dan Peraturan Presiden Nomor 44 Tahun 2017 Tentang Perubahan Atas Peraturan Presiden Nomor 12 Tahun 2010 Tentang Badan Nasional Pengelola Perbatasan yang mengamanatkan tugas BNPP yaitu menetapkan kebijakan program pembangunan perbatasan, menetapkan rencana kebutuhan anggaran, mengkoordinasikan pelaksanaan; dan melaksanakan evaluasi dan pengawasan. Sedangkan pelaksana teknis pembangunan dilakukan oleh instansi teknis sesuai tugas pokok dan fungsinya.
\end{abstract}

Kata Kunci: Perbatasan, Badan Nasional Pengelola Perbatasan, Indonesia.

\section{PENDAHULUAN}

Perbatasan negara dapat diartikan sebagai batas-batas territorial yang memisahkan wilayah negara yang satu dengan yang lainnya sekaligus menunjukkan batasbatas kedaulatan sebuah negara. Wilayah perbatasan memiliki peran yang sangat penting bagi keamanan negara. Perbatasan menjadi sebuah area yang vital bagi negara karena

Jurnal Ilmu Sosial dan Pendidikan kestabilan keamanan negara akan berdampak sangat serius terhadap pembangunan negara dalam berbagai bidang.

Wilayah perbatasan merupakan wilayah yang secara geografis berbatasan langsung dengan negara berdasarkan Undang - Undang No. 43 Tahun 2008 tentang Wilayah Negara. Berdasarkan Peraturan Pemerintah Nomor 49 Tahun 2018 Tentang Rencana Tata 
Jurnal Ilmu Sosial dan Pendidikan

http://ejournal.mandalanursa.org/index.php/JISIP/index

Terakreditasi Peringkat 5 (No. SK: 85/M/KPT/2020)

Ruang Nasional (RTRWN) maka wilayah perbatasan ditetapkan sebagai Kawasan Strategis Nasional dari sudut pandang pertahanan dan keamanan.

Perbatasan memiliki 2 (dua) pengertian, yaitu boundaries dan frontiers. Dalam konteks boundaries, perbatasan merupakan garis pemisah wilayah antarnegara. Adapun dalam konteks frontier, perbatasan lebih merujuk pada jalur (zona) yang membentang dan memisahkan 2 (dua) wilayah negara.

Konstitusi Indonesia, khususnya pada Pasal 25A Undang-Undang Dasar Tahun 1945 (UUD 1945) menyatakan bahwa "Negara Kesatuan Republik Indonesia adalah sebuah negara kepulauan yang berciri Nusantara dengan wilayah yang batas-batas dan hakhaknya ditetapkan dengan undang-undang". Lebih lanjut dalam UU No.43 Tahun 2008 tentang Wilayah Negara dinyatakan bahwa Wilayah Negara Kesatuan Republik Indonesia adalah salah satu unsur negara yang merupakan satu kesatuan wilayah daratan, perairan pedalaman, perairan kepulauan dan laut teritorial beserta dasar laut dan tanah di bawahnya, serta ruang udara di atasnya, termasuk seluruh sumber kekayaan yang terkandung di dalamnya.

Kedua ketentuan di atas menekankan pentingnya pengelolaan atas wilayah negara dan wilayah yurisdiksi negara untuk merealisasikan cita-cita bangsa terwujudnya "kesejahteraan dan kemakmuran rakyat Indonesia" dengan memperhatikan kekhususan pada karakter negara kepulauan. Sebagai konsekuensinya maka karakter Negara Indonesia sebagai negara kepulauan yang berciri nusantara harus senantiasa tercermin dalam setiap regulasi dan kebijakan dalam pengelolaan wilayah negara termasuk pengelolaan perbatasan negara, dimana perbatasan negara meliputi 2 (dua) dimensi, yaitu dimensi "Batas Wilayah Negara", dan "Kawasan Perbatasan". Berdasarkan UndangUndang Nomor 43 tahun 2008, yang dimaksud dengan: "Batas Wilayah Negara" adalah garis batas yang merupakan pemisah kedaulatan suatu negara yang didasarkan atas hukum internasional, sedangkan "Kawasan
Vol. 5. No. 1 Januari 2021

p-ISSN: 2598-9944 e- ISSN: 2656-6753

Perbatasan" adalah bagian dari Wilayah Negara yang terletak pada sisi dalam sepanjang batas wilayah Indonesia dengan negara lain, dalam hal Batas Wilayah Negara di darat, Kawasan Perbatasan berada di Kecamatan. Dalam hal batas wilayah negara di laut, berdasarkan penjelasan Pasal 13 Ayat (1) PP No.26/2008 tentang Rencana Tata Ruang Wilayah Nasional (RTRWN), yang dimaksud dengan "Kawasan Perbatasan Negara" adalah wilayah Kabupaten/Kota yang secara geografis dan demografis berbatasan langsung dengan negara tetangga dan/atau laut lepas. Kawasan perbatasan negara meliputi kawasan perbatasan darat dan kawasan perbatasan laut, termasuk pulau-pulau kecil terluar.

Kewenangan Pemerintah Pusat dalam pengelolaan wilayah negara dan kawasan perbatasan menurut Pasal 10 Undang-Undang Nomor 43 tahun 2008 adalah sebagai berikut: (1)menetapkan kebijakan pengelolaan dan pemanfaatan wilayah negara dan kawasan perbatasan; (2)mengadakan perundingan dengan negara lain mengenai penetapan batas wilayah negara sesuai dengan ketentuan peraturan perundang-undangan dan hukum internasional; (3) membangun atau membuat tanda batas wilayahnegara; (4)melakukan pendataan dan pemberian nama pulau atau kepulauan serta unsur geografis lainnya; (5)memberikan izin kepada penerbangan internasional untuk melintasi wilayah udara teritorial pada jalur yang telah ditentukan dalam peraturan perundang-undangan; (6)memberikan izin lintas damai kepada kapalkapal asing untuk melintasi laut teritorial dan perairan kepulauan pada jalur yang telah ditentukan dalam peraturan perundangundangan; (7)melaksanakan pengawasan di zona tambahan yang diperlukan untuk mencegah pelanggaran dan menghukum pelanggar peraturan perundang-undangan di bidang bea cukai, fiskal, imigrasi, atau saniter di dalam wilayah negara atau laut teritorial; (8)menetapkan wilayah udara yang dilarang dilintasi oleh penerbangan internasional untuk pertahanan dan keamanan; (9)membuat dan memperbarui peta wilayah negara dan menyampaikan kepada Dewan Perwakilan Rakyat (DPR) sekurang-kurangnya setiap 5 
(lima) tahun sekali; dan (10)menjaga keutuhan, kedaulatan dan keamanan wilayah negara serta kawasan perbatasan.

Kemudian di dalam Pasal 12 Dalam Pasal dijelaskan bahwa Pemerintah Kabupaten/Kota dalam pengelolaan wilayah negara dan kawasan perbatasan berwenang (Pasal 12 Undang-Undang Nomor 43 Tahun 2008 ) : melaksanakan kebijakan pemerintah dan menetapkan kebijakan lainnya dalam rangka otonomi daerah dan tugas pembantuan; menjaga dan memelihara tanda batas; melakukan koordinasi dalam rangka pelaksanaan tugas pembangunan di kawasan perbatasan di wilayahnya; dan melakukan pembangunan kawasan perbatasan antarpemerintah daerah dan/atau antara pemerintah daerah dengan pihak ketiga. Untuk mengelola batas wilayah negara dan mengelola kawasan perbatasan pada tingkat pusat dan daerah, pemerintah dan pemerintah daerah membentuk badan pengelolaan nasional dan badan pengelolaan daerah. Badan pengelolaan tersebut dipimpin oleh seorang kepala badan yang bertanggung jawab kepada Presiden atau kepala daerah sesuai dengan kewenanganya.

Dilansir dari halaman website resmi Badan Nasional Pengelola Perbatasan (BNPP) dijabarkan visi dan misi Badan Nasional Pengelola Perbatasan yaitu, BNPP memiliki Visi terwujudnya tata kelola perbatasan negara yang efektif dalam rangka perwujudan kawasan perbatasan negara sebagai halaman depan negara yang berdaya saing. Dan misi (1) Meningkatkan efektifitas dalam penetapan kebijakan dan program pembangunan perbatasan; (2) Meningkatkan efektifitas dalam penetapan rencana kebutuhan anggaran pengelolaan perbatasan negara; Meningkatkan efektifitas dalam fasilitasi dan koordinasi pelaksanaan pengelolaan perbatasan negara; (4) Meningkatkan efektifitas dalam pelaksanaan evaluasi dan pengawasan pengelolaan perbatasan negara.

Berdasarkan uraian pada latar belakang masalah diatas, maka dirumuskan masalahnya yaitu, bagaimana peran Badan Nasional Pengelola Perbatasan di dalam melakukan pengawasan terhadap perbatasan nasional?

\section{METODE PENELITIAN}

Metode pendekatan yang digunakan dalam penelitian ini adalah yuridis normatif. Metode penelitian ini merupakan metode penelitian hukum kepustakaan dimana metode atau cara yang dipergunakan di dalam penelitian hukum dilakukan dengan cara meneliti bahan pustaka yang ada. Tahapan pertama penelitian hukum normatif adalah penelitian yang ditujukan untuk mendapatkan hukum obyektif (norma hukum), yaitu dengan mengadakan penelitian terhadap masalah hukum. Tahapan kedua penelitian hukum normatif adalah penelitian yang ditujukan untuk mendapatkan hukum subjektif (hak dan kewajiban). Relevansi pendekatan penelitian ini adalah untuk mengetahui dan memperoleh pengetahuan mengenai peran Badan Nasional Pengelola Perbatasan di dalam melakukan pengawasan terhadap perbatasan nasional.

\section{PEMBAHASAN DAN ANALISIS}

Pengelolaan keamanan negara terutama di wilayah perbatasan saat ini setidaknya didasarkan pada 2 (dua) paradigma besar yakni pendekatan state security dan human security. State security berorientasi pada keamanan territorial negara yakni untuk menjaga kedaulatan dan keutuhan negara dengan pengerahan kekuatan militer. state security, hanya mencakup area politik dan militer, diamana keamanan negara hanya dapat terwujud bila dikawal secara ketat oleh militer. Konsep keamanan kemudian mengalami perluasan makna, dari keamanan negara menjadi keamanan individu atau yang disebut dengan human security.

Human security mulai menjadi prioritas ketika isu-isu kesejahteraan, sosial, dan lingkungan hidup mengemuka. Kebutuhan akan keamanan manusia yang terpenuhi merupakan modal utama bagi upaya menjaga keamanan negara. Pendekatan tersebut menekankan pada aspek kemanan manusia dalam pengertian luas yakni keamanan akan faktor ekonomi, kesehatan, dan lainnya.

Terdapat 3 (tiga) pendekatan aliran pemikiran human security yakni:

(1) pendekatan yang memusatkan perhatian pada hak asasi manusia 
(2) pendekatan yang menekankan pada keselamatan manusia

(3) pendekatan yang menekankan pada usahausaha pembangunan secara berkelanjutan.

Kemudian setidaknya terdapat 7 (tujuh) elemen spesifik yang terkandung di dalamnya yakni:

(1) keamanan ekonomi

(2) keamanan pangan

(3) keamanan kesehatan

(4) keamanan lingkungan hidup

(5) keamanan personal (dapat berupa keamanan fisik seperti kekerasan, kecelakaan dan lain-lain)

(6) keamanan sosial budaya, dan

(7) keamanan politik.

Berdasarkan hal tersebut diatas, maka dapat dilihat bahwa permasalahan di wilayah perbatasan tidak hanya sebatas keamanan negara saja, namun sudah sangat luas hingga hampir mengenai beberapa aspek pada kehidupan masyarakat.

Isu strategis aktivitas lintas batas di kawasan perbatasan berupa fenomena yang terjadi dengan dua makna yakni isu berdampak negatif dan positif. Sebagian besar isu strategis aktivitas lintas batas berupa isu (permasalahan) yang merupakan akibat dari kondisi aktivitas lintas batas yang ada di kawasan perbatasan. Kawasan perbatasan yang belum dianggap sebagai pintu gerbang negara, masih terkondisi dengan kurangnya sarana dan prasarana pelayanan yang memadai, belum optimalnya pengelolaan SDA lokal, belum adanya peningkatan kualitas SDM perbatasan, masih minimnya sarana pertahanan dan keamanan, dsb. Dengan kondisi tersebut mengakibatkan munculnya isu strategis aktivitas lintas batas di kawasan perbatasan darat, laut, dan udara. Terkait dengan gambaran mengenai isu strategis aktivitas lintas batas, maka berikut ini akan dijelaskan secara lebih rinci mengenai isu strategis aktivitas lintas batas dari sudut pandang manajemen atau pengelolaan isu-isu sentral dalam aktifitas lintas batas, yaitu isu Manajemen Pintu Gerbang, Manajemen SDA dan Lingkungan Lintas Batas, dan Manajemen Kerjasama Sosial-Ekonomi Lintas Batas.
Pengelolaan batas wilayah negara pada dasarnya dilakukan untuk mencapai keberadaan arah strategis mewujudkan kawasan perbatasan sebagai wilayah yang aman, baik secara kedaulatan negara, ketertiban, serta keamanan kawasan.

Pembangunan dan pelayanan pintu gerbang di perbatasan harus dilakukan berdasarkan tujuan dan sasaran strategis, yaitu optimalnya pembangunan dan pelayanan aktivitas lintas batas Negara Indonesia. Oleh sebab itu beberapa strategi yang dapat ditetapkan dalam pembangunan dan pelayanan pintu gerbang adalah sebagai berikut:

a. Membangun fasilitas PLBN berteknologi tinggi menuju Smart Border Gate. Fasilitas PLBN yang direncanakan akan dibangun pada tahun 2020 berdasarkan Inpres No. 1/2019 tentang Percepatan Pembangunan Pos Lintas Batas Negara Terpadu dan Sarana Prasarana Penunjang di kawasan perbatasan, sebagai berikut:

1) Serasan, di Kecamatan Serasan, Kab. Natuna, Prov. Kep. Riau.

2) Jagoi Babang, Kecamatan Jagoi Babang, Kab. Bengkayang, Prov. Kalbar.

3) Sei Kelik/Jasa, Kecamatan Ketungau Hulu, Kab. Sintang, Prov. Kalbar.

4) Sei Nyamuk, Kecamatan Sebatik Utara, Kab.Nunukan, Prov. Kaltara.

5) Labang, Kecamatan Lumbis Ogong, Kab. Nunukan, Prov.Kaltara.

6) Long Midang, Kecamatan Krayan, Kab.Nunukan, Prov.Kaltara.

7) Long Nawang, Kecamatan Kayan Hulu, Kab. Malinau, Prov.Kaltara.

8) Oepoli, Kecamatan Amfoang Timur, Kab.Kupang, Prov.NTT.

9) Napan, Kecamatan Bikomi Utara, Kab. TTU, Prov. NTT.

10) Yetetkun, Distrik Ninati, Kab. Boven Digoel, Prov. Papua.

b. Membangun Area disekitar PLBN sebagai fasilitas sosial-ekonomi untuk pemantik dalam membangkitkan perekonomian masyarakat. Membangun fasilitas sosialekonomi berupa pusat perbelanjaan atau pasar yang digunakan untuk memantik 
aktivitas ekonomi masyarakat di perbatasan.

c. Menyusun kebijakan pengelolaan dan pelayanan pintu gerbang non-PLBN. Pelayanan pintu gerbang di perbatasan antara Indonesia dengan negara tetangga tidak harus dalam bentuk PLBN, sehingga diperlukan penyusunan kebijakan pengelolaan dan pelayanan pintu gerbang non-PLBN yang mempunyai hirarki dibawah PLBN.

Selain beberapa hal yang sudah disebutkan di atas, BNPP menjelaskan di dalam Rencana Induk Tahun 2020 tentang Penanganan dan Penegakan Hukum Lintas Batas Negara yaitu akan dibangun Sarana dan Prasarana Pengamanan dan Penegakan Hukum Lintas Batas Negara, berupa pembangunan Pos Pengamanan Terpadu di setiap PLBN yang didalamnya terdapat petugas keamanan dari TNI, Polri dan Satuan Pengamanan PLBN. Peraturan Kepala BNPP Nomor 7 (tujuh) Tahun 2017 tentang Pedoman Pengelolaan Pos Lintas Batas Negara, mengatur peran POLRI dan TNI sebagai kekuatan pendukung penyelenggaraan pelayanan lintas batas negara. Dalam konteks pengelolaan PLBN, POLRI dan TNI memiliki peran masingmasing.

Dalam konteks pengelolaan PLBN, termasuk dalam penyelenggaraan pelayanan lintas batas negara, khususnya pada aktivitas yang berlangsung di dalam gedung PLBN, POLRI sebagai unsur penegak hukum tidak terlibat secara langsung namun keterlibatan POLRI dalam penyelenggaraan pelayanan lintas batas negara bersifat sebagai kekuatan pendukung. Oleh karenanya, POLRI lebih banyak berperan dalam memberikan perlindungan dan pengayoman serta pelayanan kepada masyarakat di luar kawasan PLBN. Dalam hal dibutuhkan, Kepala Bidang Pengelolaan PLBN/Administrator PLBN dapat meminta bantuan POLRI untuk penanganan masalah-masalah pelanggaran hukum yang terjadi di PLBN dan kawasan PLBN.

Sebagai kekuatan pertahanan negara, TNI tetap dibutuhkan dalam melindungi kepentingan nasional dari ancaman dan gangguan terhadap keutuhan bangsa dan negara yang mungkin terjadi di PLBN dan/atau kawasan PLBN. Pelaksanaan peran TNI dilakukan sesuai dengan kebutuhan berdasarkan informasi yang disampaikan oleh Kepala Bidang Pengelolaan PLBN/Administrator PLBN terkait dengan dinamika situasi dan kondisi di PLBN dan/atau kawasan PLBN. Operasionalisasi tata kelola pengamanan PLBN dan aktualisasi peran POLRI dan TNI, Unit Pengelola PLBN menyediakan tempat atau ruang kerja bagi personil POLRI dan personil TNI yang diberi tugas oleh kepala satuan atau komandan satuan masing-masing sebagai pejabat penghubung antara POLRI dan TNI dan Unit Pengelola PLBN.

Dalam rangka Pencegahan dan Pemberantasan Penyalahgunaan dan Peredaran Gelap Narkoba (P4GN) di Kawasan Perbatasan, khususnya di PLBN upaya yang dilakukan oleh BNPP bersama dengan Badan Narkotika Nasional (BNN), secara khusus di PLBN Entikong telah disediakan posko bersama yang dapat dimanfaatkan BNN dan instansi terkait (Tim Interdiksi) untuk pengendalian dan pengawasan kejahatan penyelundupan narkoba yang melalui perbatasan.

Peran Serta Masyarakat dalam Pengamanan dilintas Batas Negara

Telah diterbitkan Peraturan Kepala BNPP Nomor 12 Tahun 2015 tentang Pedoman Pembinaan Garda Batas Republik Indonesia, merupakan upaya untuk meningkatan peran serta masyarakat berperan aktif dalam membantu petugas dalam menjaga dan memelihara keamanan di kawasan perbatasan negara.

Indonesia memiliki beberapa hubungan kerjasama regional kawasan dengan negara tetangga. Salah satu bentuk kerjasama adalah kerjasama lintas batas antarnegara. Kerjasama ini dalam bentuk perjanjian dasar antarnegara ataupun implementasi bersama terkait pelintas batas. Perjanjian ini menyepakati beberapa substansi antara lain:

1) The border area;

2) Joint border committee and consultation;

3) Liaison arrangements; 
4) Border crossings for traditional and customary purpose;

5) Excersie of tradisional rights to land and waters in the border area;

6) Border crossing by nontraditional inhabitants;

7) Disaster and accidents;

8) Customary border trade.

Kerjasama strategis Indonesia dengan negara tetangga juga dilakukan pada sektor ekonomi. Kerjasama ekonomi dengan negara tetangga antara lain Indonesia Malaysia Singapore Growth Triangle (IMS-GT), BIMP - EAGA (Brunei, Indonesia, Malaysia and Philippines - East ASEAN Growth Area), Indonesia Malaysia Thailand- Growth Triangle (IMT-GT) dan Austraian-Indonesia Development Area (AIDA). Berikut ini akan diuraikan mengenai bentuk kerjasama ekonomi kawasan Indonesia dengan negara tetangga. Salah satu kerjasama internasional yang dilaksanakan adalah perdagangan bebas kawasan berupa ASEAN Free Trade Area (AFTA) yang sudah dimulai tahun 2015, merupakan bentuk kerjasama negara-negara ASEAN di bidang ekonomi yang merupakan suatu persetujuan dalam pengelolaan sektor produksi produksi lokal yang ada di seluruh negara-negara ASEAN tanpa kecuali. Selain itu sedang dipersiapkan rencana terbentuknya blok perdagangan yang dikenal sebagai Kemitraan Ekonomi Komprehensif Regional (Regional Comprehensive Economic Partnership-RECP) melibatkan 10 negara ASEAN, plus Cina, Selandia Baru, India, Jepang, dan Korea Selatan. Oleh karena itu Indonesia dituntut untuk mempersiapkan diri.

Kembali melihat Undang-Undang Nomor 43 Tahun 2008 Tentang Wilayah Negara dan Peraturan Presiden Nomor 44 Tahun 2017 Tentang Perubahan Atas Peraturan Presiden Nomor 12 Tahun 2010 Tentang Badan Nasional Pengelola Perbatasan yang mengamanatkan tugas BNPP yaitu menetapkan kebijakan program pembangunan perbatasan; menetapkan rencana kebutuhan anggaran; mengkoordinasikan pelaksanaan; dan melaksanakan evaluasi dan pengawasan. Sedangkan pelaksana teknis pembangunan

dilakukan oleh instansi teknis sesuai tugas pokok dan fungsinya.

$$
\text { Evaluasi dan Pengawasan }
$$

dilaksanakan dengan berpedoman pada Peraturan Pemerintah No. 39 Tahun 2006 tentang Tata Cara Pengendalian dan Evaluasi Pelaksanaan Rencana Pembangunan. Evaluasi ini merupakan bagian yang penting sebagai hilir dari semua rangkaian proses perencanaan dan pelaksanaan suatu progam atau kegiatan. Evaluasi dimaksudkan untuk menilai pencapaian hasil dan pengetahuan kemajuan maupun kendala yang dijumpai dalam pelaksanaan sehingga dapat dinilai untuk perbaikan pelaksanaan rencana pembangunan di masa yang akan datang, karena evaluasi menjadi titik awal perbaikan perencanaan program pembangunan batas wilayah negara dan kawasan perbatasan berikutnya.

\section{KESIMPULAN}

Pengelolaan batas wilayah negara pada dasarnya dilakukan untuk mencapai keberadaan arah strategis mewujudkan kawasan perbatasan sebagai wilayah yang aman, baik secara kedaulatan negara, ketertiban, serta keamanan kawasan.

visi dan misi Badan Nasional Pengelola Perbatasan yaitu, BNPP memiliki Visi terwujudnya tata kelola perbatasan negara yang efektif dalam rangka perwujudan kawasan perbatasan negara sebagai halaman depan negara yang berdaya saing. Dan misi (1) Meningkatkan efektifitas dalam penetapan kebijakan dan program pembangunan perbatasan; (2) Meningkatkan efektifitas dalam penetapan rencana kebutuhan anggaran pengelolaan perbatasan negara; (3) Meningkatkan efektifitas dalam fasilitasi dan koordinasi pelaksanaan pengelolaan perbatasan negara; (4) Meningkatkan efektifitas dalam pelaksanaan evaluasi dan pengawasan pengelolaan perbatasan negara.

BNPP menjelaskan di dalam Rencana Induk Tahun 2020 tentang Penanganan dan Penegakan Hukum Lintas Batas Negara yaitu akan dibangun Sarana dan Prasarana Pengamanan dan Penegakan Hukum Lintas Batas Negara, berupa pembangunan Pos Pengamanan Terpadu di setiap PLBN yang 
didalamnya terdapat petugas keamanan dari TNI, Polri dan Satuan Pengamanan PLBN. Peraturan Kepala BNPP Nomor 7 (tujuh) Tahun 2017 tentang Pedoman Pengelolaan Pos Lintas Batas Negara, mengatur peran POLRI dan TNI sebagai kekuatan pendukung penyelenggaraan pelayanan lintas batas negara. Dalam konteks pengelolaan PLBN, POLRI dan TNI memiliki peran masingmasing.

Kerjasama strategis Indonesia dengan negara tetangga juga dilakukan pada sektor ekonomi. Kerjasama ekonomi dengan negara tetangga antara lain Indonesia Malaysia Singapore Growth Triangle (IMS-GT), BIMP - EAGA (Brunei, Indonesia, Malaysia and Philippines - East ASEAN Growth Area), Indonesia Malaysia Thailand- Growth Triangle (IMT-GT) dan Austraian-Indonesia Development Area (AIDA). Berikut ini akan diuraikan mengenai bentuk kerjasama ekonomi kawasan Indonesia dengan negara tetangga. Salah satu kerjasama internasional yang dilaksanakan adalah perdagangan bebas kawasan berupa ASEAN Free Trade Area (AFTA) yang sudah dimulai tahun 2015, merupakan bentuk kerjasama negara-negara ASEAN di bidang ekonomi yang merupakan suatu persetujuan dalam pengelolaan sektor produksi produksi lokal yang ada di seluruh negara-negara ASEAN tanpa kecuali.

\section{SARAN}

Di dalam melaksanakan tugas dan fungsi nya, BNPP harus lebih mengoptimalkan kinerja nya di dalam melakukan pengawasan pada lintas batas negara, mengingat pentingnya perbatasan bagi suatu negara.

Salah satunya seperti dengan lebih memelihara dan memantau aktivitas di sekitar patok batas Negara, mendorong partisipasi masyarakat dalam pengamanan perbatasan (sesuai UU Nomor 43 tahun 2008 bab VII Pasal 19), mengembangkan teknologi informasi geospasial untuk pengamanan patok batas negara, membangun area disekitar PLBN sebagai fasilitas sosial-ekonomi untuk pemantik dalam membangkitkan perekonomian masyarakat dan menegakkan hukum terhadap aktivitas ilegal di kawasan perbatasan Darat.

\section{UCAPAN TERIMA KASIH}

Terima kasih kepada rekan-rekan sejawat pada Badan Nasional Pengelola Perbatasan yang telah memberikan dukungan serta masukan terhadap penelitian ini.

\section{DAFTAR KEPUSTAKAAN}

BNPP, Visi dan Misi BNPP, dikutip dari <http://bnpp.go.id/halaman/detail/vis i-dan-misi-bnpp>, tanggal 10 Desember 2020.

Djaka, Marwasta, Kajian Daerah Tentang Rencana Pembentukan Kabupaten Muyu Pemekaran dari Kabupaten Boven Digoel Provinsi Papua, kerjasama Pemerintah Kabupaten Boven Digoel dan Program S2 Politik Lokal dan Otonomi Daerah, Universitas Gadjah Mada Yogyakarta, 2009.

Indonesia, Peraturan Pemerintah Nomor 26 Tahun 2008 tentang Rencana Tata Ruang Wilayah Nasional (RTRWN).

Indonesia, Peraturan Pemerintah Nomor 39 Tahun 2006 tentang Tata Cara Pengendalian dan Evaluasi Pelaksanaan Rencana Pembangunan.

Indonesia, Peraturan Pemerintah Nomor 49 Tahun 2018 tentang Rencana Tata Ruang Nasional (RTRWN).

Indonesia, Peraturan Presiden Nomor 44 Tahun 2017 tentang Perubahan Atas Peraturan Presiden Nomor 12 Tahun 2010 Tentang Badan Nasional Pengelola Perbatasan.

Indonesia, Undang-Undang Dasar Tahun 1945.

Indonesia, Undang-undang Nomor 43 Tahun 2008 tentang Wilayah Negara, Lembaran Negara Republik Indonesia Tahun 2008 Nomor 177., dan Tambahan Lembaran Negara (TLN) Nomor 4925.

Paris, Roland, "Human Security: Paradigma Shift or Hot Air?" dalam International Security, Vol. 26. 
Pratikno,Pendampingan Pengelolaan Wilayah Perbatasan Di Indonesia: Lesson Learned dari KKN-PPM UGM di Kawasan Perbatasan, Vol. 01 No.2, 2016.

Rencana Induk Badan Nasional Pengelola Perbatasan Tahun 2020.

Sanak, Yohanes, Human Security dan Politik Perbatasan, (Bandung: Alumni).

Soekanto, Soerjono dan Sri Mamudji, Penelitian Hukum Normatif, (Jakarta: PT. Raja Grafindo Persada, 2003). 